\title{
Article \\ Formation of an Export-Oriented Agricultural Economy and Regional Open Innovations
}

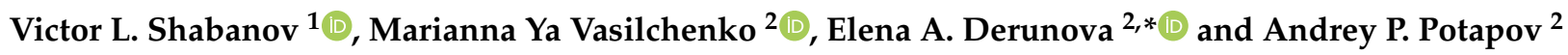 \\ 1 Sociological Faculty, Saratov State University, 410012 Saratov, Russia; vic35@inbox.ru \\ 2 Laboratory for Innovative Development of The Production Potential of The Agro-Industrial Complex, \\ Institute of Agrarian Problems of the Russian Academy of Sciences, 410012 Saratov, Russia; \\ mari.vasil4enko@yandex.ru (M.Y.V.); appotapov@mail.ru (A.P.P.) \\ * Correspondence: ea.derunova@yandex.ru
}

Citation: Shabanov, V.L.;

Vasilchenko, M.Ya.; Derunova, E.A.;

Potapov, A.P. Formation of an

Export-Oriented Agricultural Economy and Regional Open Innovations. J. Open Innov. Technol.

Mark. Complex. 2021, 7, 32

https://doi.org/10.3390/joitmc7010032

\begin{abstract}
The aim of the work is to find relevant indicators for assessing the relationship between investments in fixed assets in agriculture, gross output of the industry, and agricultural exports using tools for modeling the impact of innovation and investment development on increasing production and export potential in the context of the formation of an export-oriented agricultural economy. The modeling methodology and the proposed estimating and forecasting tools for diagnosing and monitoring the state of sectoral and regional innovative agricultural systems are used to analyze the relationship between investments in fixed assets in agriculture, gross output of the industry, and agricultural exports based on the construction of the classification of Russian regions by factors that aggregate these features to diagnose incongruence problems and to improve institutional management in regional innovative export-oriented agrosystems. Based on the results of the factor analysis application, an underestimated role of indicators of investment in agriculture, the intensity and efficiency of agricultural production, were established. Based on the results of the cluster analysis, the established five groups of regions were identified, with significant differences in the level of investment in agriculture, the volume of production of the main types of agricultural products, and the export and exported food. The research results are of practical value for use in improving institutional management when planning reforms and transformations of regional innovative agrosystems.
\end{abstract}

Keywords: innovation and investment development; cluster analysis; principal components method; regional agricultural systems; government support

\section{Introduction}

In modern conditions, the development of innovative and investment activities in agriculture is a driver for ensuring food security and increasing the export potential of the agro-industrial complex of countries. The problem of the formation of an export-oriented regional agrarian economy in both the leading agrarian-oriented countries and Russia is inextricably linked with an increase in the efficiency of the introduction of innovative technologies and high-tech products in agricultural production.

Foreign researchers mark the development of new technologies and methods of cultivation of agricultural crops as one of the priorities of sustainable agriculture [1].

The transfer of agriculture to a new technological basis is reflected in the use of software methods to create optimal projects in agriculture [2].

At the same time, a high degree of differentiation of Russian regions in terms of geographic location, natural and climatic conditions, and level of resource provision acts as a significant restriction on the formation of new export positions, prejudging the need to develop a differentiated state policy for each type of region and substantiate key strategies for managing innovation and investment activities in order to strengthen the multiplier effect of investment not only for production, but also for export. 
The territorial and sectoral aspect of agricultural production in the development and implementation of innovations actualizes the problem of analyzing the quality of innovation and investment development, finding tools for diagnosing, and quantitatively measuring regional innovation and investment activity. The formation of an export-oriented policy in the agricultural sector in the territorial context requires an in-depth understanding of the factors affecting the rate of innovative growth of agriculture in the regions.

The academic contribution of this study is in the use of cluster modeling methodology and tools to analyze the relationship between investments in fixed assets in agriculture, gross industrial output, and agricultural exports. In this study, we develop tools for diagnosing incongruence problems and improving institutional management in regional innovative export-oriented agrosystems.

The aim of the work is to find relevant indicators for assessing the relationship between investments in fixed assets in agriculture, gross output of the industry, and agricultural exports using tools for modeling the impact of innovation and investment development on increasing production and export potential in the context of the formation of an exportoriented agricultural economy.

The study tested the following hypotheses:

Hypothesis 1 (H1). The imperfection of the assessment and forecasting development toolkit does not allow for effective management of innovation processes in regional agricultural systems.

Hypothesis 2 (H2). The underestimated impact of investments on production and exports slows down the level of innovative activity in agriculture.

The work sets and solves the following logically related tasks:

> Generalization of theoretical and methodological approaches to study the essence of innovation and investment activities in regional agricultural systems in the formation of an export-oriented agricultural sector of the economy.

$>$ Content analysis of scientific publications on the use of hierarchical regional classification in the study of problems of the functioning of regional agricultural systems.

$>$ Systematization of factors of production, investment, and export potential of the agroindustrial complex of Russia when conducting a hierarchical regional classification.

$>$ Revealing the relationship between investments in fixed assets in agriculture, gross output of the industry, and export of agricultural products based on the classification of Russian regions by factors that aggregate these characteristics and characterize production, investment, and export potential.

$>$ Substantiation of the main directions for improving innovation and investment activities by groups of regions of the selected clusters, contributing to an increase in the efficiency of agricultural production and the creation of an export-oriented agricultural sector of the economy.

$>$ Substantiation of theoretical and methodological approaches to model the impact of innovation and investment development on the formation of an export-oriented agricultural sector of the economy.

The modeling methodology and the proposed assessment and forecasting tools for diagnosing and monitoring the state of sectoral and regional innovative agricultural systems are used to analyze the relationship between investments in fixed assets in agriculture, gross output of the industry, and agricultural exports based on the classification of Russian regions by factors that aggregate these signs and the development of recommendations for increasing the innovation and investment activity of regional agricultural systems in the context of the formation of an export-oriented economy.

The novelty of the approach lies in the possibility of applying a differentiated approach to the development of tools and strategies of state regulation in accordance with the typology of regions based on the results of the cluster analysis and the development of measures to improve the development of the regional system of the agricultural economy. 
The results can be taken into account in the formation of the innovation and investment policy of the export-oriented agricultural economy. The results indicate the possibility of using the developed assessment and forecasting tools for diagnosing and monitoring the state of sectoral and regional innovative agricultural systems and their balanced sustainable development.

The research results are of practical value in the development of mechanisms for increasing the efficiency of innovation and investment activities for the formation of an export-oriented agricultural sector of the economy.

This work is organized as follows.

$>$ The purpose, main research questions, and novelty of the approach are in the first section.

$>$ The literature review and theoretical background of the study are discussed in the second section.

$>\quad$ The third section presents the methodology for researching cluster modeling.

$>$ The empirical results of the cluster modeling process from the point of view of the relationship between investments in fixed assets in agriculture, the gross output of the industry, and agricultural exports and the typology of regions are presented in the fourth section.

$>\quad$ In the fifth section, we discuss the research results and directions for improving development strategies and recommend a set of policies for each cluster of regions.

$>$ The sixth section presents conclusions, recommendations, research limitations, and suggestions for further research.

\section{Theoretical Framework}

\subsection{Literature Review}

\subsubsection{Diffusion Processes of Innovation}

The mechanisms and speed of knowledge dissemination between the subjects of innovative activity of agricultural systems determine the effectiveness of ensuring food security and independence of national economies and increasing their export potential. In the modern global world, the effective formation of export-oriented industrial and regional agricultural systems is associated with the creation of their own innovations and the application of external opportunities. The flexibility of regional innovative agricultural systems to spread innovations allows them to be more efficient, sustainable, and dynamic. Consequently, the problem of innovative diffusion processes for sustainable, balanced export-oriented development is of considerable research interest. Many classical and modern studies are devoted to this issue.

\subsubsection{Author's Paradigm}

The formation of the author's paradigm of increasing innovation and investment activity in order to accelerate the development of export-oriented agricultural sector is described with the position of the synthesis of theories of innovation and national innovation systems, theory of investment and trade flows, international trade theory, the theory of innovation clusters, and the theory of the three-phase development of the economy by Chenery H. and Strout A.

a. The concept of the national innovation system (NIS). The main theoretical and methodological views of the National Innovation System (NIS) concept was developed by Freeman C. [3], Lundvall B.-A. [4], and Nelson R., who are supporters of the views of Schumpeter J. and Hayek F. The NIS is reduced to such postulates that knowledge is a factor of economic growth, that the development of the NIS occurred due to the process of diffusion of innovation, that the institutional component of any economic system determines and adjusts the rate of the diffusion of innovations, and that the creation, implementation, and commercialization of new knowledge in time and space increases the spillover effects of their distribution. Among the support structures for agricultural research, according to the World Bank (2006), there are National Agricultural Research 
Systems (NARS), Agricultural Innovation System (AIS), and Agricultural Knowledge and Information System (AKIS).

b. Open innovation concept. The Russian Federation, like other countries of the world, is interested in studying the phenomenon of open innovation in all sectors of the economy, including agriculture. At the same time, for agriculture, the restrictions on the use of open innovations are the insufficient financing of innovative business, imperfection of the system of statistical accounting of innovative activity, imperfection of regulation of relations in the field of intellectual property, and insufficient competence of highly qualified human resources for high-tech innovative business. This is why it is imperative to develop a model to analyze the dynamic effects of open innovation strategies and to model open innovation for the choice of future strategies in agriculture [5].

Improving the efficiency of innovation and investment activities in agriculture and the agro-industrial complex is associated with the creation, implementation, distribution, and commercialization of innovations, taking into account the needs of regions and specific features of agricultural production; the adaptation of foreign digital systems; and the growth of integration interaction between educational, scientific, production, and implementation formations, as described by Aker J [6].

c. Spatial development. The theories of "new economic geography," particularly the theory of international and interregional trade by Krugman P., justifies the placement of scientific and intellectual investment, production, information, and other resources in regions where the agglomeration effect is identified due to a complex of mutually influencing factors. Regions are divided into high-tech "main zones" and less-developed "peripheries" [7].

d. Export-oriented development. The level of provision with the investment resources is the most important condition for economic growth and export expansion. The theory of three-phase economic development by Chenery H. and Strout A. identifies various stages of saturation of the economy with investments and the degree of their use. The economy's need for additional investments indicates the process of import substitution and export growth [8].

\subsubsection{Contribution of Innovation to Efficiency Gains}

a. Al-Hassan R., Egyir I., Abakah J. [9] considered the development of innovation and investment activities in developing countries, where the growth rate of agriculture, on the one hand, is ahead of the world due to favorable natural and climatic conditions. On the other hand, it is slowed down due to an undeveloped infrastructure, the complexity of investment policies, and insufficiently developed mechanisms of state support at the regional level, as well as a low level of digitalization of agricultural production.

At the same time, it is necessary to take into account that the ongoing climatic changes around the world significantly worsen the conditions for the functioning of agriculture and make it difficult to solve the problem of food security. Climate change is accompanied by an increase in demand for energy, food, and water. Consequently, the problem of adaptation to the observed climate changes is becoming one of the main tasks for sustainable agriculture, which requires realizing economic and environmental goals through the use of modern technologies [10].

b. The works of Allaire G., Boyer R., Barbier E., Reardon T. [11], Bush L., and Bain C. [12] have analyzed the main directions of network interaction and the transfer of knowledge and technologies.

c. Contributions of innovations to improve the efficiency of production processes in agricultural systems have been presented in the works of Autor D. H. [13], Gandhi R., Veetaraghavan R., Toyama K. [14], Dasgupta S., Mamingi N. [15], Oliver Y., Robertson M., and Wong M. [16].

$\mathrm{d}$. The possibilities of adapting advanced scientific and technological achievements in agriculture at the federal and regional levels of the enterprise have been reviewed in 
the studies of Rios D. L., Srivastava L., Chaddad F., Reardon T. [17], Humphrey J., and Schmitz H. [18].

The analysis of foreign and domestic literature has made it possible to identify two research areas for innovative development of the agro-industrial complex. Foreign researchers are guided by the strategy of technological leadership and the positive experience of forming cluster structures in developed countries, where the focus is mainly on the scientific and technological development of large companies, agricultural holdings, and multinational corporations that are suppliers of high-tech products to agribusiness of other countries.

Russian scientists are guided by the priority role of the state in the development of scientific and intellectual potential of agribusiness, the application of program-target approach to the development of the high-tech agricultural sector and agriculture in the regions, and the formation of a systematic innovation process with increased interest in agribusiness at all stages of the chain, which is secured by the investment and infrastructure support at all levels of the hierarchy [19].

\subsubsection{Innovation and Investment Development}

In domestic and foreign literature, there are different approaches to the essence of investment and innovation activities in agriculture. Innovative development of various levels of the hierarchy of the national economy, including the agro-industrial complex and agriculture, is reflected in the works of Sandu I. S., Altukhov A. I., Ushachev I. G., Nechaev V. I., Tatarkin A. I., Lazovsky V. V., and Semenova E. I. According to Altukhov A. I., it is necessary to develop the methodology of multifunctionality and multiactivity in agricultural production to ensure the level of profitability of the agricultural sector in the economy required by modern realities in order to transform it into a science-intensive and high-tech sector [20].

On 5 September 2015, the UN General Assembly adopted Resolution 70/1 “Transforming our world: the 2030 Agenda for Sustainable Development," which reflected 17 sustainable development goals, including the elimination of hunger (goal 2). Although the fight against hunger is not a priority for Russia, food security issues are quite relevant. The current activities described in the state program for the development of agriculture and regulation of markets for agricultural products, raw materials, and food for the period 2013-2024 are in line with the objectives of Resolution 70/1. These include increasing agricultural productivity, building sustainable food production systems, increasing investment in agriculture, and ensuring the proper functioning of food markets [21].

\subsection{Theoretical Aspects of the Formation of an Innovative Export-Oriented Policy}

\subsubsection{Investment Policy}

An important role is assigned to the use of effective investment models and mechanisms aimed at improving the competitiveness of the agricultural sector and increasing export potential, which requires defining tasks and mechanisms that take into account previously set priorities. Thus, the main directions for improving investment policy are measures to encourage investment in the priority subsectors of agriculture [22].

The important role of the latest investment and innovation tools, models, and mechanisms, which aims at increasing the competitiveness of the agricultural sector, as well as increasing export potential, is noted by Russian scientists. In this connection, in order to address the issues of increasing the activity of economic entities in the field of innovation, it is necessary to develop a targeted agricultural innovation policy which defines tasks and mechanisms that take into account previously set priorities.

\subsubsection{Support for Innovative Development}

Policy harmonization at the federal and regional levels is the key to the implementation of the task. Meanwhile, the mechanism of state support for innovative reproduction in rural areas should be built in such a way that it directly stimulates the procedure for 
changing technological patterns [23]. All of the above points to the need to improve the investment policy as its main directions are measures to encourage investment in the priority subsectors of agriculture [24].

\subsubsection{Export Vector of the Agricultural Sector}

In this regard, it is relevant to develop theoretical and methodological approaches to research of the impact of innovation and investment activities on the formation of exportoriented agricultural systems at the regional and industry levels of management; to develop assessment and forecast tools for diagnosing the relationship between investment in fixed assets of agriculture, gross output of the industry, and export of agricultural products on the basis of a classification of Russian regions by factors aggregating these characteristics; and to develop directions for improving the state of the innovative-investment policy in the agricultural sector of the economy for various types of clusters.

\section{Materials and Methods}

\subsection{Indicators for Statistical Analysis}

The previously formulated goal of the study (to find relevant indicators for assessing the relationship between investments in fixed assets in agriculture, gross output of the industry, and agricultural exports using tools for modeling the impact of innovation and investment development on increasing production and export potential in the context of the formation of an export-oriented agricultural economy) determines the choice of indicators for statistical analysis.

The list includes 8 indicators-absolute indicators characterizing the production and export of agricultural products and relative ones characterizing the scale of food exports, the capital intensity of agricultural products, and the efficiency of agricultural production (Table 1).

Table 1. The list of indicators involved in the statistical analysis.

\begin{tabular}{ll}
\hline$X_{1}$ & Export of food products and agricultural raw materials, million US dollars \\
\hline$X_{2}$ & Share of exports of food and agricultural raw materials in the total export volume, $\%$ \\
\hline$X_{3}$ & Gross agricultural output per 1 ha of agricultural land, thousand rubles \\
\hline$X_{4}$ & $\begin{array}{l}\text { Investments in fixed assets aimed at the development of agriculture, per } 1000 \text { rubles of } \\
\text { gross output, RUB. }\end{array}$ \\
\hline$X_{5}$ & Export of cereals and legumes, thousand tons \\
\hline$X_{6}$ & Export of meat (including offal) and meat products, thousand tons in slaughter weight \\
\hline$X_{7}$ & Gross grain harvest (in weight after completion), thousand tons \\
\hline$X_{8}$ & Production of livestock and poultry for slaughter (in slaughter weight), thousand tons \\
\hline
\end{tabular}

The use of multidimensional analysis methods is also determined by the purpose of the work. The formalized identification of relationships between the selected indicators enables us to formulate not only economically but also statistically sound recommendations for improving the investment activity of agricultural systems in the regions of Russia.

\subsection{Cluster Analysis Method}

Unlike stochastic frontier analysis (SFA) [25], which has become widely used in foreign studies, as one of the stochastic modeling methods used in most cases for analyzing technical efficiency, the choice of cluster analysis allows for a spatial specification with the selection of groups of regions according to the corresponding features.

A similar conclusion applies to the use of the Malmquist Productivity Index (MPI) [26], as described by Caves D.W., Christensen L.R., and Diewert W.E. [27]. MPI allows for the estimation of the threshold values of factor productivity at the enterprise level in most 
cases under conditions of uncertainty. Data Envelopment Analysis (DEA) is also used to measure and evaluate the performance of enterprises [28-30].

The result of applying cluster analysis in this study was the classification of Russian regions into several groups with a high degree of uniformity in the set of indicators. The grouping of regions by the cluster analysis method was preceded by a reduction in the dimension of the feature space by the method of principal components of factor analysis. The need to apply factor analysis in economic research, including in this study, is related to the difficulties arising from the use of multidimensional classification methods with a large number of variables, some of which are correlated.

To achieve the final goal - the classification of regions - at the first stage, the dimensionality reduction was carried out by the method of principal components of factor analysis due to the difficulties that arise when using the methods of multivariate classification with a large number of variables, some of which are correlated.

In the dimensionality reduction process, closely correlated variables are combined into new ones, generalized and uncorrelated, which retain most of the information about the original variables (explaining most of their overall variance). Formally, these generalized variables are linear combinations of the original normalized variables, the coefficients, before which are factor loads varying from -1 to 1 . The factor loads characterize the strength of the influence of the corresponding indicator on the main component.

As a result, the feature space is compressed and its axes are orthogonalized, which increases the efficiency of subsequent multidimensional classification along these axes using one of the cluster analysis methods. The additional value of using of the principal component method is the possibility of their subsequent semantic interpretation, showing internal latent dependencies between the original features [31-35].

The use of the hierarchical method of Ward with squared Euclidean distance as proximity measure in this work is based on the fact that its algorithm leads to a sufficiently high homogeneity of the clusters. It is illustrated by the tree building of the step-by-step merging of clusters. Initially, each object is treated as a separate cluster. Then, there is a consistent association based on the selected proximity measure until there is only 1 left. The algorithm is completed on a given number of clusters, which is determined based on expert considerations [36].

\subsection{Possibilities of Using Cluster Analysis}

Let us take a closer look at several works that have used methods of dimension reduction and hierarchical regional classification. Shubat O. M. and. Shmarova I. V. classified the subjects of the Russian Federation according to 4 indicators that characterize the state of the family institution. According to the results of classification, 4 clusters were identified that differed in the level of problems in the family sphere [37].

In the study of Larina T. N., the classification of rural municipal districts of the Orenburg region on the basis of 3 main components, obtained as a result of reducing the dimension of the initial 9-dimensional feature space characterizing the development of rural infrastructure, was carried out. According to the classification results, the leading regions in the development of social infrastructure were identified [38]. It is also important to note the work of Guzairov M. B., Degtyareva I. V., and Makarova E. A., in which 2 main components based on 13 indicators characterizing the consumption of food by the population, final expenditures, and the Gini coefficient were identified. This made it possible to present the results of the subsequent classification of the subjects of the Russian Federation in 2-dimensional space [39]. The research on investment potential using cluster analysis is described in the work by Raiskaya N. N., Sergienko Ya. V., and Frenkel A. A. To classify regions by the level of investment potential, 13 socioeconomic and financial indicators were used, including exports and imports and research and development costs. As a result of the study, the classification of Russian regions by investment potential was carried out with the allocation of 4 cluster group. The authors also provided recommendations for improving the organizational and economic mechanism of investment activity [40]. The 
work of researchers from Kuban State Agrarian University, which applied cluster analysis to analyze the efficiency of milk production in the Krasnodarsky region, also correlates with the topic of the given article [41]. Ruchinskaya L. V. also used the above method in the classification of regions by the scale of production and consumption of dairy products [42].

The possibilities of using cluster analysis were realized in the study of regional conditions for the development of dairy and meat cattle breeding in Russia, which identified cluster groups based on a set of characteristics that reflected the intensity of milk and meat production [43].

Taking the above into account, we consider it reasonable to choose the methods of multivariate analysis, which is also determined by the purpose of the work. Formalized identification of the relationships between the selected indicators make it possible to formulate not only economically but also statistically sound recommendations for increasing the investment activity of agricultural systems in the regions of Russia.

\subsection{Statistical Base and Software}

The statistical base of this study includes data for 69 regions-subjects of the Russian Federation - those that contained complete information on the 8 declared indicators. All calculations were performed using the SPSS statistical information processing and analysis package.

\section{Results}

\subsection{Calculation Algorithm}

Based on the results of factor analysis of the initial variables $\mathrm{X}_{1} \ldots \mathrm{X}_{8}$, distributed across 69 regions of Russia and normalized according to the standard procedure leading to a 0 mean and a single variance, 3 main components were obtained that explained $78.3 \%$ of the total variance. The rotation of the principal component space by the Varimax method led to a clearer distribution of the factor loads of the initial normalized indicators into the main components. The resulting matrix of factor loads with a fairly simple structure made it possible to unambiguously correlate the initial indicators with the main components (Table 2).

Table 2. Matrix of factor loads.

\begin{tabular}{cccc}
\hline & & Component & \\
\cline { 2 - 4 } & MC1 & MC2 & MC3 \\
\hline$X_{1}$ & 0.880 & 0.023 & 0.237 \\
\hline$X_{2}$ & 0.321 & -0.090 & 0.812 \\
\hline$X_{3}$ & 0.078 & 0.710 & 0.373 \\
\hline$X_{4}$ & -0.139 & 0.273 & 0.529 \\
\hline$X_{5}$ & 0.976 & 0.059 & 0.024 \\
\hline$X_{6}$ & 0.050 & 0.950 & 0.088 \\
\hline$X_{7}$ & 0.885 & 0.272 & -0.077 \\
\hline$X_{8}$ & 0.224 & 0.921 & -0.099 \\
\hline
\end{tabular}

The highest factor loads in absolute value (those exceeding 0.5 were chosen as such) determined the indicators for which a meaningful interpretation of the main components was given. The first main component (MC1), which explained $33.6 \%$ of the total variance, was formed by three indicators with high factor loads, $X_{1}, X_{5}$, and $X_{7}$. All of them were included in $\mathrm{MC1}$ with one sign, that is, the dynamics of indicators were unidirectional. All indicators were absolute: The total export of food and agricultural raw materials were determined by the gross production and total export of grain. In other words, food and 
agricultural exports are directly linked to the grain production and export. MC1 can be interpreted as "food and agricultural exports and their main factors."

The second main component (MC2) explained $30.2 \%$ of the total variance. Three indicators with high factor loads- $X_{3}, X_{6}, X_{8}$-were included in it with one sign. The relative value of gross agricultural output (per 1 ha of farmland) was directly related to the absolute indicators of livestock and poultry production (in slaughter weight) and export of meat products. This means that the efficiency of agricultural production is directly related to meat and meat products. MC2 can be interpreted as "the efficiency of agricultural production and its main factors."

The third main component (MC3) explained $14.5 \%$ of the total variance. It consisted of two relative indicators, $\mathrm{X}_{2}$ and $\mathrm{X}_{4}$, included in $\mathrm{MC} 3$ with one sign. Investment in agriculture (per RUB 1000 of gross output) was directly related to the growth of the share of agricultural products in the total export volume. MC 3 shows that the higher the capital intensity of agricultural products, the higher the share of agricultural products in exports is. The investments in agriculture produce the export of agricultural products, and the investments in agriculture are made to increase its exports. MC3 can be interpreted as "intensive investment in agriculture and export of agricultural products."

It should be noted that, judging by the shares of total variance explained by each main component in this factor model, investment in the agricultural sector is inferior in importance and significance for the rural economy to the production and export indicators, and relative indicators that characterize intensity and efficiency are inferior to absolute indicators that characterize gross volumes.

\subsection{Calculation Results}

According to the results of the Ward method classification based on three selected principal components, five clusters were formed. The Belgorod and Rostov regions and Krasnodar territory made up two separate clusters that joined the general tree of hierarchical classification in the last steps (Figure 1).

These regions differ significantly from others in their high specialization. The Belgorod region is a leader in the production and export of livestock and poultry meat, and the Rostov region and the Krasnodar territory are leaders in the production and export of grain. In our model, this was formally reflected in the high values of MC2 and MC1 for these regions.

The remaining regions formed 3 clusters-clusters 2, 3, and 4, containing 11, 21, and 34 federal subjects, respectively. In Figure 1, it can be seen that cluster 3 was the most compact, consisting of two groups of regions which were united at one of the first steps of clustering. Cluster 2 was the least compact due to the fact that a group of rather isolated regions with significant features-the Kamchatka territory, Kaliningrad region, and Chechen Republic-joined it at one of the middle steps. Cluster 4 was also formed by combining two compact groups of different sizes ( 28 and 6 subjects of the Russian Federation) at one of the middle steps, one of which (including the republics of Mordovia, Mariy El, Tatarstan, Stavropol territory, Lipetsk and Chelyabinsk regions) was determined by high values of MC1 and MC2.

Let us have a look at the composition of these three clusters. Geographically, cluster 3 and, to a lesser extent, cluster 2 were divided into several territorial regions, of which the most complete and numerous were represented by the regions of western and central Russia. In addition, cluster 3 had a significant representation of the Far East and North Caucasus. Cluster 4 was the most numerous and extended geographically. Despite this, it was one of the most compact. Cluster 4 was formed at the fourth step of clustering, when a group of 6 regions mentioned above joined the 28 "main" regions. 


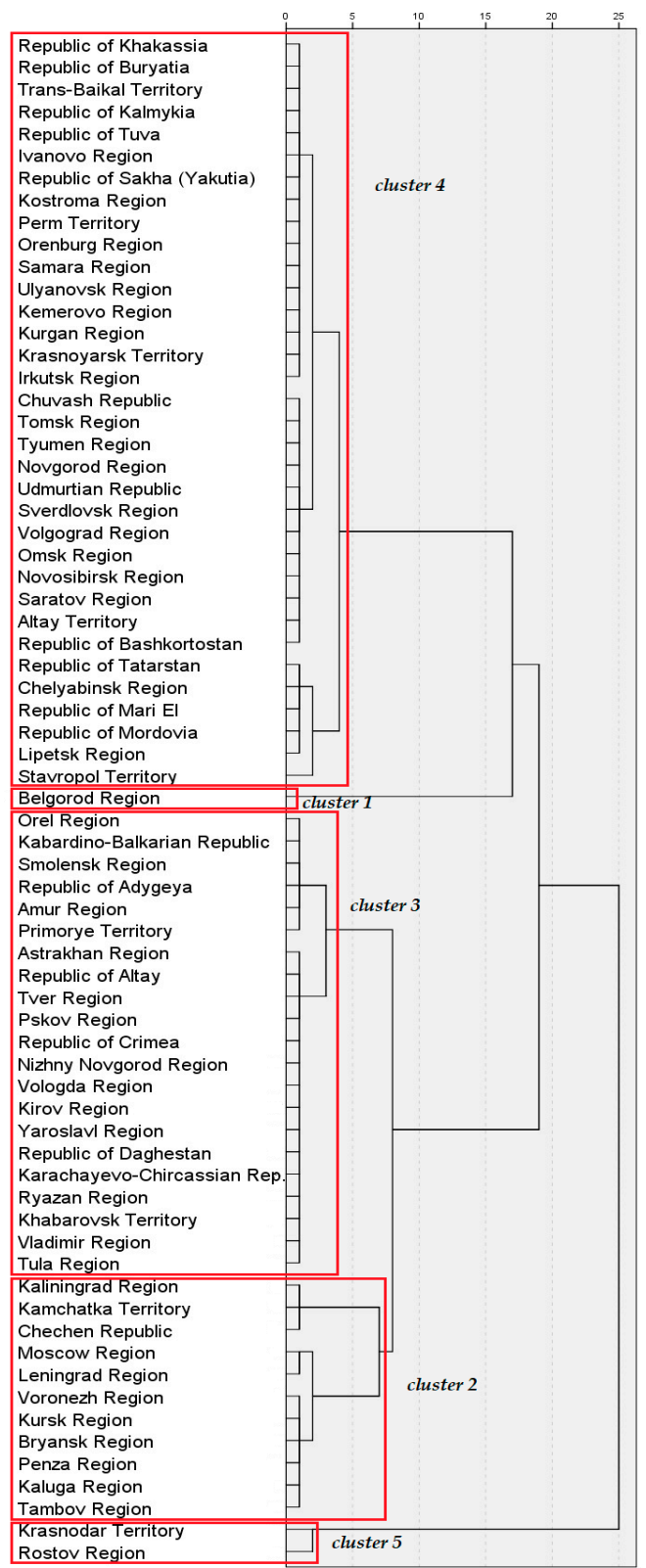

Figure 1. The hierarchical classification tree (dendrogram): Using the Ward method, with the Euclidean distance square as a measure.

The use of the hierarchical Ward method with the squared Euclidean distance as a measure of proximity in this work is justified by the fact that this algorithm led to a sufficiently high homogeneity of clusters and was illustrative due to the construction of a tree of step-by-step cluster unification. First, each object was considered as a separate cluster. Then, their sequential unification took place based on the chosen measure of proximity until there is only one left. The algorithm ended on a given number of clusters, which was determined based on expert considerations.

\subsection{Characteristics of Clusters}

The number of clusters was established on the basis of a visual analysis of the hierarchical classification tree (dendrogram, Figure 1). The seventh step was taken as the threshold step, at which cluster 2 was formed. Further unification at subsequent steps of the clustering process was impractical due to a sharp decrease in compactness in the formed clusters. Thus, the clustering process led to the formation of 5 clusters, including 3 large 
clusters containing 11, 21, and 34 constituent entities of the Russian Federation (clusters 2, 3,4 , respectively), and 2 small and isolated clusters, joining the general the hierarchical classification tree in the last steps. The regions included in these two clusters significantly differ from the others in their high specialization. The Belgorod region (cluster 1) is the leader in the production and export of livestock and poultry meat, the Rostov region and Krasnodar Territory (cluster 5) are the leaders in the production and export grains. In our model, this was formally reflected in the high values of GC2 and GC1 for these regions.

4.3.1. Average Values of the Main Components for Each Cluster

Characteristics and Visualization of Clusters

Table 3 shows the average values of the main components for each cluster.

Table 3. Average values of the main components in clusters.

\begin{tabular}{cccc}
\hline Cluster & MC1 & MC2 & MC3 \\
\hline 1 & -0.213 & 6.022 & -0.962 \\
2 & -0.190 & 0.664 & 1.568 \\
3 & -0.299 & -0.358 & 0.403 \\
4 & -0.055 & -0.174 & -0.740 \\
5 & 5.238 & 0.060 & 0.197 \\
\hline
\end{tabular}

One can see that clusters 1 and 5 were the absolute leaders in terms of MC2 and MC1. Without taking into consideration cluster 1 (Belgorod region), cluster 2 becomes the leader in MC2. The regions of this group were characterized by high values of agricultural production efficiency and its main factors-gross production and export of meat. Indeed, eight regions in cluster 2, excluding the three that joined the main group at one of the middle steps (the Kaliningrad region, Chechen Republic, and Kamchatka territory), had high MC2 values. These eight regions of cluster 2 were among the first 15 following the Belgorod region in terms of MC2 values, and six regions were directly behind the Belgorod region (together with the Lipetsk region from cluster 4). When switching to the initial indicators, these regions showed the highest values for the Russian Federation for the total agricultural output per 1 ha of farmland (RUB 1000) and the export of meat and meat products (thousand tons in slaughter weight), and one of the highest in the production of livestock and poultry (thousand tons in slaughter weight).

Cluster 5, which includes the Krasnodar territory and the Rostov region, was the undisputed leader in terms of MC1 values. The 15 regions following them in terms of MC1 values were part of clusters 4 and 2 (the only exception was the Primorsk territory from cluster 3, which had one of the highest indicators of agricultural exports in the Russian Federation). The 15 regions were the Stavropol and Altai territories, Saratov, Volgograd, Omsk, Orenburg, Samara, Lipetsk, the Republic of Tatarstan, and Bashkortostan in cluster 4, and the Voronezh, Kursk, Tambov, and Kaliningrad regions in cluster 2. They were characterized by fairly high indicators of gross production and export of grain and exports of agricultural products in general, although these indicators were noticeably inferior to the Krasnodar territory and Rostov region.

MC3 had the highest values in cluster 2 and, to a lesser degree, in cluster 3. Among the 18 leading regions in terms of MC3 values, 11 were in cluster 2, and cluster 3 included 14 regions. Thus, MC3 was the leading differentiating feature in the formation of clusters 2 and 3. The average values of MC3 for all clusters, including 2 and 3, were statistically distinguishable (with a significance level of 0.05 according to the $t$-criterion).

The average values of statistical indicators used in the calculations for clusters that characterize production, investment, and export potential are shown in Table 4. The distribution of regions-subjects of the Russian Federation by cluster is shown on the map (Figure 2). 
Table 4. Characteristics of clusters by level of production, investment and export potential.

\begin{tabular}{|c|c|c|c|c|c|c|c|c|}
\hline $\begin{array}{l}\text { Groups of Subjects of } \\
\text { the Russian Federation }\end{array}$ & $\begin{array}{c}\text { Exports of } \\
\text { Food } \\
\text { Products } \\
\text { and Agricultural Raw } \\
\text { Materials, Million us } \\
\text { Dollars } \\
\end{array}$ & $\begin{array}{l}\text { Share of Exports of } \\
\text { Food } \\
\text { and Agricultural Raw } \\
\text { Materials in Total } \\
\text { Exports, \% }\end{array}$ & $\begin{array}{l}\text { Gross Agricultural } \\
\text { Output Per } 1 \text { ha of } \\
\text { Agricultural Land, } \\
\text { Thousand Rubles }\end{array}$ & $\begin{array}{l}\text { Investments in Fixed } \\
\text { Capital Aimed at the } \\
\text { Development of } \\
\text { Agriculture, per } 1000 \\
\text { Rubles of Gross } \\
\text { Output, RUB }\end{array}$ & $\begin{array}{c}\text { Export of Cereals and } \\
\text { Legumes (Including } \\
\text { Export), Thousand } \\
\text { Tons }\end{array}$ & $\begin{array}{c}\text { Export of Meat } \\
\text { (Including Offal) and } \\
\text { Meat Products } \\
\text { (Including Export), } \\
\text { Thousand Tons in } \\
\text { Slaughter Weight }\end{array}$ & $\begin{array}{c}\text { Gross Grain Harvest } \\
\text { (in Weight After } \\
\text { Completion), } \\
\text { Thousand Tons }\end{array}$ & $\begin{array}{c}\text { Production of } \\
\text { Livestock and } \\
\text { Poultry for Slaughter } \\
\text { (in the } \\
\text { Slaughterhouse), } \\
\text { Thousand Tons } \\
\end{array}$ \\
\hline $\begin{array}{c}\text { Cluster } 1 \\
\text { (Belgorod region) }\end{array}$ & 351.2 & 10.5 & 135.6 & 51.3 & 331.5 & 1230.7 & 3385.8 & 1322.9 \\
\hline $\begin{array}{l}\text { Cluster } 2 \\
\text { (11 regions) }\end{array}$ & 386.2 & 41.8 & 62.9 & 143.1 & 987.3 & 270.2 & 1586.1 & 220.6 \\
\hline $\begin{array}{l}\text { Cluster } 3 \\
\text { (21 regions) }\end{array}$ & 150.2 & 21.0 & 33.7 & 89.8 & 344.7 & 47.5 & 622.5 & 71.5 \\
\hline $\begin{array}{l}\text { Cluster } 5 \\
\text { (2 regions) }\end{array}$ & 4006.9 & 45.3 & 61.0 & 56.7 & $23,649.0$ & 173.1 & $11,818.9$ & 322.3 \\
\hline
\end{tabular}




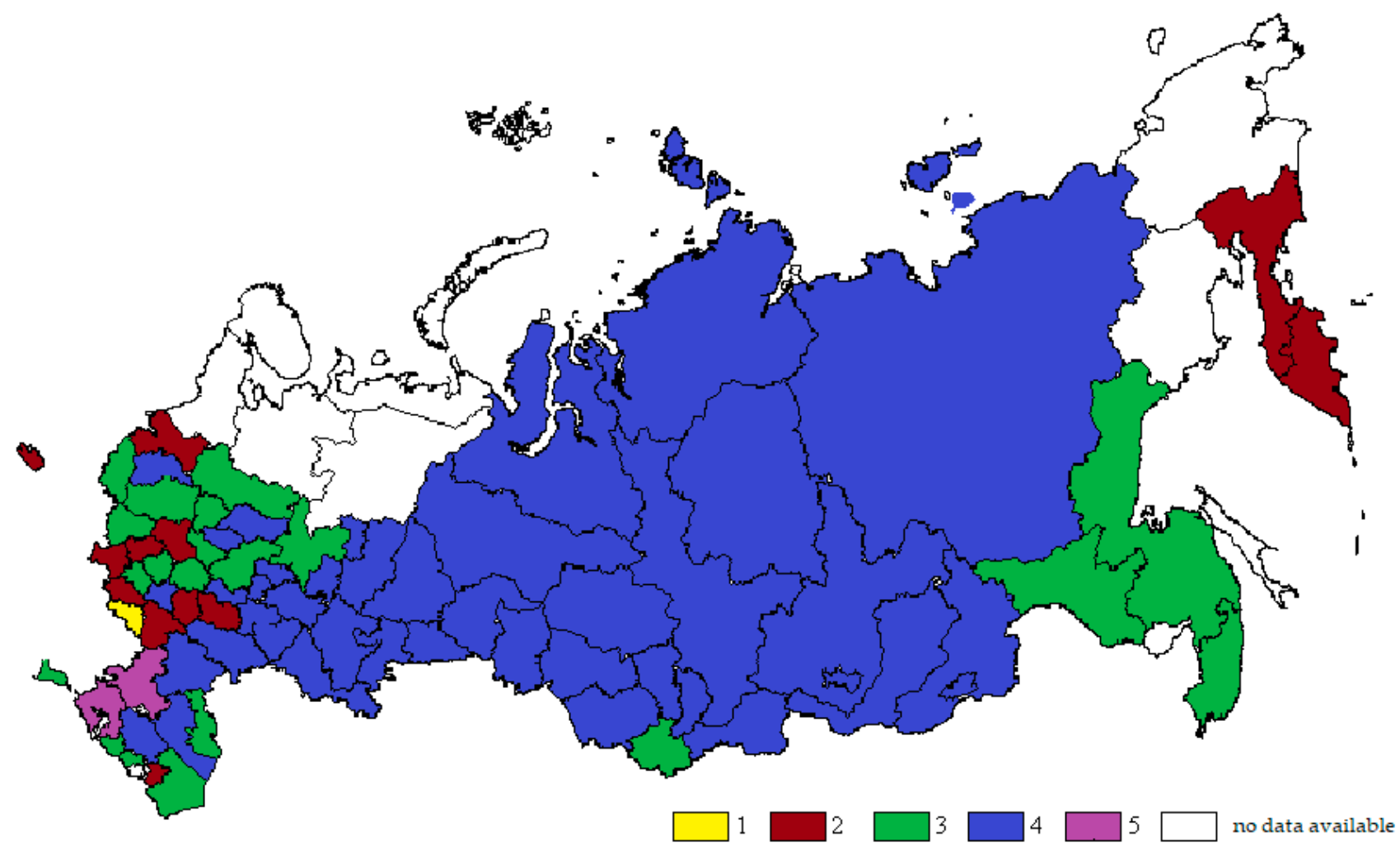

Figure 2. Map of distribution of regions—subjects of the Russian Federation by cluster.

Thus, the regions of cluster 2 as a whole were characterized by leading positions in terms of MC3 and MC2 values in terms of the intensity of investment in agriculture, the intensity of agricultural exports, the efficiency of agricultural production, and the associated gross production and export of meat and meat products. The highest values of all the five monitored indicators were in the Bryansk, Voronezh, Kursk, and Tambov regions. The highest values of four indicators were in the in the Moscow and Penza regions, and three were in the Kaliningrad and Leningrad regions.

\subsubsection{Cluster Composition}

The following clusters were marked with appropriate hatching:

1. Belgorod region.

2. Bryansk region, Voronezh region, Kaluga region, Kursk region, Moscow region, Tambov region, Kaliningrad region, Leningrad region, Chechen Republic, Penza region, Kamchatka territory.

3. Vladimir region, Oryol region, Ryazan region, Smolensk region, Tver region, Tula region, Yaroslavl region, Vologda region, Pskov region, Republic of Adygea, Republic of Crimea, Astrakhan region, Republic of Dagestan, Kabardino-Balkar Republic, Karachay-Cherkessia, Kirov region, Nizhny Novgorod region, Altai Republic, Primorsky territory, Khabarovsk territory, Amur region.

4. Ivanovo Region, Kostroma Region, Lipetsk Region, Novgorod Region, Volgograd Region, Republic of Kalmykia, Stavropol Territory, Republic of Bashkortostan, Republic of Mari El, Republic of Mordovia, Republic of Tatarstan, Orenburg Region, Samara Region, Saratov Region, Perm Territory, Ulyanovsk Region, Udmurtian Republic, Chuvash Republic, Kurgan Region, Sverdlovsk Region, Tyumen Region, Chelyabinsk Region, Republic of Tuva, Republic of Khakassia, Altai Territory, Krasnoyarsk Territory, Irkutsk Region, Kemerovo Region, Novosibirsk Region, Omsk Region, Tomsk Region, Republic of Buryatia, Republic of Sakha (Yakutia), Trans-Baikal Territory. 
5. Krasnodar territory, Rostov region.

6. Due to the lack of necessary statistical data, the following regions of Russia were not included in the calculations: Arkhangelsk Region, Murmansk Region, Republic of Karelia, Komi Republic, Republic of Ingushetia, Republic of North OssetiaAlania, Magadan Region, Sakhalin Region, Jewish Autonomous Region, Chukotka Autonomous Area, Moscow, Sevastopol.

\subsection{Interregional Differentiation}

Turning to the initial indicators, let us point out the high values of investment in agriculture (per RUB 1000 of gross output) in the regions of cluster 2. Out of 10 leading regions in Russia, in which the amount of investment per RUB 1000 of gross output exceeds RUB 150, 6 regions represented this cluster: The Kaluga, Penza, Moscow, Bryansk, Kaliningrad, and Voronezh regions. The other four regions, the Smolensk, Tver, Oryol, and Kirov regions, represented cluster 3.

Empirically, the volume of investment determines the dynamics of labor productivity through the introduction of technological innovations, the concentration of capital, and an increase in the efficiency of its use [44].

High indicators of investment, meat production, and exports are achieved here due to the implementation of large-scale projects in animal husbandry. For example, in 2019, a plant processing turkey meat was put into operation in Penza region, with an average annual capacity of 155,000 tons. Major projects in pig farming are operating in the Penza, Voronezh, and Tver regions.

High values of MC3 were also typical for cluster 3. The leading regions in terms of investment were the four regions listed above: The Smolensk, Tver, Oryol, and Kirov regions. At the same time, cluster 3 had low values of MC1 and MC2, which characterized the weak development of grain and meat production and export and general export of food and agricultural raw materials in the regions of the cluster.

Cluster 4 regions were characterized by low values of MC2 and MC3. These regions had less-developed meat production and export were, and the intensity of investment was lower. At least 10 regions of the cluster listed above were among the leaders in the Russian Federation in terms of MC1 values (in terms of gross grain harvest and export and in terms of total exports of food and agricultural raw materials). Among them, the Stavropol territory ranked seventh in Russia in terms of wheat exports in 2018 (Bread Sale: How Russia became the leader in wheat exports, and farmers began to go broke in the United States URL: https: / / realnoevremya.ru/articles/136213-analiz-eksporta-pshenicy-rf-poregionam-i-prodavcam). It is noteworthy that, in this region, the intensity of the investment, expressed by the indicator of "Investment in fixed capital aimed at the development of agriculture, 1000 rub. of gross output" (RUB 67.4), was significantly above the average for cluster 4, ahead of Ivanovo region (RUB 13.9), Samara region (RUB 24.1), Saratov region (RUB 29.6), the Republic of Bashkortostan (RUB 35.6), and the Republic of Tatarstan (RUB 48.6).

One of the conditions for the further development of the investment potential of Stavropol region is the growth of real incomes of subjects of agribusiness.

One can notice that the best overall position in production and export of grain and meat and investments in agriculture was the Rostov region and Krasnodar territory, which formed a separate cluster 5 . The Belgorod region, which formed a separate cluster 1 , had the highest efficiency of the gross production of agricultural products, production of livestock and poultry, and the export of meat. At the same time, the Belgorod region was inferior in most of the other considered parameters. In particular, the region's investment in agriculture was RUB 51.3 to RUB 1000 gross output (38th place out of 69 regions under consideration). This situation is explained by the dominance of Belgorod region in a number of agricultural indicators, including production volumes. In 2018, the region ranked second in Russia in terms of gross agricultural output (RUB 257,038 million). The forced lag in the above indicator can be explained from the standpoint of the scale effect 
of production [45], especially since the region is 1 of the 10 largest regions in terms of investment in agriculture and has a high innovative potential.

The authors of [46] examined the problems of interregional differentiation in terms of food security and proposed approaches to clustering regional agri-food systems according to the criteria of independence, physical, and economic accessibility of food, as well as development stability. The authors empirically substantiated that the use of the food independence indicator in the food security model is relevant only for the development of agricultural systems at the federal level. At the regional level, the main criteria for the food security model are the physical and economic availability of food for all groups of the population and the sustainability of the functioning of agorosystems. The authors of [47] developed approaches to institutional management for balanced sustainable development of regional systems, taking into account the needs of the regions on the basis of the cognitive modeling methodology. The authors identified the main regularities in the regional system and substantiated the growth directions of the main target macroeconomic indicators of the systems functioning, taking into account the synergistic effect of strengthening interaction of regional actors.

\subsection{Export Procedures}

The creation of the export potential of agricultural production is based on the innovative development of the entire industry, an increase in the competitiveness of products, the development of a system for promoting domestic goods to foreign markets through procedures for agreeing on requirements for agricultural products, obtaining the right to access the domestic market of the importing country, and removing restrictions on the quality and composition of the product, labeling, and packaging.

Export procedures are also supported through concessional loans under agreements to increase competitiveness, which subject to production growth; the development of commodity export infrastructure; and the organization of inspection trips of representatives of foreign countries to enterprises producing agricultural products in order to confirm the quality, production conditions, and compliance with standards. The author's paradigm links innovation and investment development with the formation of an export-oriented agricultural sector of the economy.

\subsection{Innovative Activity of Organizations and the Innovative Component of Exports 4.6.1. Terminology of Innovation}

In the following presentation of the material, the terminology of innovation is used, developed by the international Oslo guide for the statistical measurement of innovation. Innovation activity is defined as all research, financial, and commercial activities aimed at creating new or improved products (goods, services), significantly different from the products previously produced and intended for introduction on the market. Innovative goods are defined as goods that are new or have undergone technological changes to varying degrees over the past 3 years (including the reporting period) [48].

The effectiveness of innovation is to compare the effect (result) of the application of innovations and the costs of their development, production, and consumption. The most important characteristic of innovation and investment development is the innovative activity of the organization. This indicator characterizes the degree of participation of an organization in the implementation of innovative activities as a whole or its individual types over a certain period of time. The level of innovation activity is calculated as the ratio of the number of organizations that have carried out technological, marketing, or organizational innovations to the total number of organizations surveyed for a certain period of time in a country, industry, or region, etc. Research has empirically proved the influence of innovation activity on the possibilities of production and on increasing the export of high-tech products. 


\subsubsection{Innovative Activity of Organizations}

To assess the innovative activity of organizations and the innovative component of exports, a number of indicators calculated by cluster groups was used (Table 5). Technological innovation plays an essential role in the development of European rural areas [49]. In agriculture in Russia, the limiting factors are the lack of funds and weak financial support from the state. It should be noted that, in Russia, as in foreign countries, regional differences in innovation activity persist $[50,51]$.

Table 5. Characteristics of clusters by the level of innovation activity of organizations and the innovative component of exports (2018).

\begin{tabular}{|c|c|c|c|c|c|c|c|c|c|}
\hline \multirow[b]{2}{*}{$\begin{array}{l}\text { Groups of } \\
\text { Subjects of } \\
\text { the Russian } \\
\text { Federation }\end{array}$} & \multicolumn{3}{|c|}{$\begin{array}{c}\text { Share of Organizations That Implemented } \\
\text { Technological Innovations in the Total } \\
\text { Number of Surveyed Organizations by Type } \\
\text { of Activity, \% }\end{array}$} & \multicolumn{3}{|c|}{$\begin{array}{c}\text { The Share of Expenditures on Technological } \\
\text { Innovations in the Total Volume of Goods } \\
\text { Shipped, Works Performed, and Services by } \\
\text { Type of Activity, \% }\end{array}$} & \multicolumn{3}{|c|}{$\begin{array}{l}\text { The Share of Innovative Products in the Total } \\
\text { Volume of Goods Shipped, Works Performed, } \\
\text { and Services in the Field of Business, \% }\end{array}$} \\
\hline & $\begin{array}{c}\text { Cultivation } \\
\text { of Grain, } \\
\text { Grain- } \\
\text { Legumes } \\
\text { and Seeds } \\
\text { of Mass } \\
\text { Crops }\end{array}$ & $\begin{array}{c}\text { Animal } \\
\text { Husbandry }\end{array}$ & $\begin{array}{c}\text { Food } \\
\text { Production }\end{array}$ & $\begin{array}{c}\text { Cultivation } \\
\text { of Grain, } \\
\text { Grain- } \\
\text { Legumes } \\
\text { and Seeds } \\
\text { of Mass } \\
\text { Crops }\end{array}$ & $\begin{array}{c}\text { Animal } \\
\text { Husbandry }\end{array}$ & $\begin{array}{c}\text { Food } \\
\text { Production }\end{array}$ & $\begin{array}{c}\text { Cultivation } \\
\text { of Cereals, } \\
\text { Legumes } \\
\text { and } \\
\text { Oilseeds }\end{array}$ & $\begin{array}{c}\text { Animal } \\
\text { Husbandry }\end{array}$ & $\begin{array}{c}\text { Food } \\
\text { Production }\end{array}$ \\
\hline $\begin{array}{l}\text { Cluster } 1 \\
\text { (Belgorod } \\
\text { region) }\end{array}$ & 19.4 & 13.0 & 45.5 & 0 & 0.3 & 2.4 & 0 & 3.7 & 17.5 \\
\hline $\begin{array}{c}\text { Cluster } 2 \\
\text { (11 regions) }\end{array}$ & 6.7 & 9.1 & 21.1 & 0.2 & 1.1 & 0.9 & 0.1 & 2.6 & 7.6 \\
\hline $\begin{array}{c}\text { Cluster } 3 \\
\text { (21 regions) }\end{array}$ & 1.8 & 2.8 & 18.3 & 0.1 & 0.1 & 0.3 & 0 & 0.3 & 0.6 \\
\hline $\begin{array}{c}\text { Cluster } 4 \\
\text { (34 regions) }\end{array}$ & 3.1 & 2.6 & 15.4 & 0.9 & 1.0 & 0.4 & 0.1 & 1.4 & 4.4 \\
\hline $\begin{array}{l}\text { Cluster } 5 \\
\text { (2 regions) }\end{array}$ & 19.3 & 10.1 & 15.0 & 1.2 & 0 & 3.2 & 2.6 & 0.1 & 3.0 \\
\hline
\end{tabular}

The analysis shows a significant degree of regional differentiation in the level of innovation activity of organizations by type of activity, which determines the possibility of production and export of high-tech products. Thus, in the first cluster, the highest share of organizations implemented technological innovations in the production of cereals, legumes, and oilseeds; livestock products; and food products (19.4\%, $13.0 \%$, and 45.5\%, respectively). For the first two positions, the data are comparable to the indicators of the fifth cluster (19.3\% and 10\%). However, in the first cluster, there were no expenditures on technological innovations in the shipped products of cereals, legumes, and oilseeds, while in the fifth cluster, their share was the most significant $(1.2 \%)$. In the first and fifth clusters, the share of expenditures on technological innovations in shipped food products $(2.4 \%$ and $3.2 \%$ ) was also higher than in other clusters, although innovation activity in this position dominated in the first cluster. The second cluster was characterized by a higher innovation activity of the activities under consideration compared to the third and fourth clusters. At the same time, this cluster (excluding cereals, legumes, and oilseeds) had a higher share of technological innovation costs in shipped products than the third and fourth clusters.

\subsubsection{An Innovative Component of Export}

An important indicator is a share of innovative products in the output, which allows us to characterize the innovation of exports to a certain extent. Figure 3 shows the relationship between food exports and innovative shipped goods for various activities. 


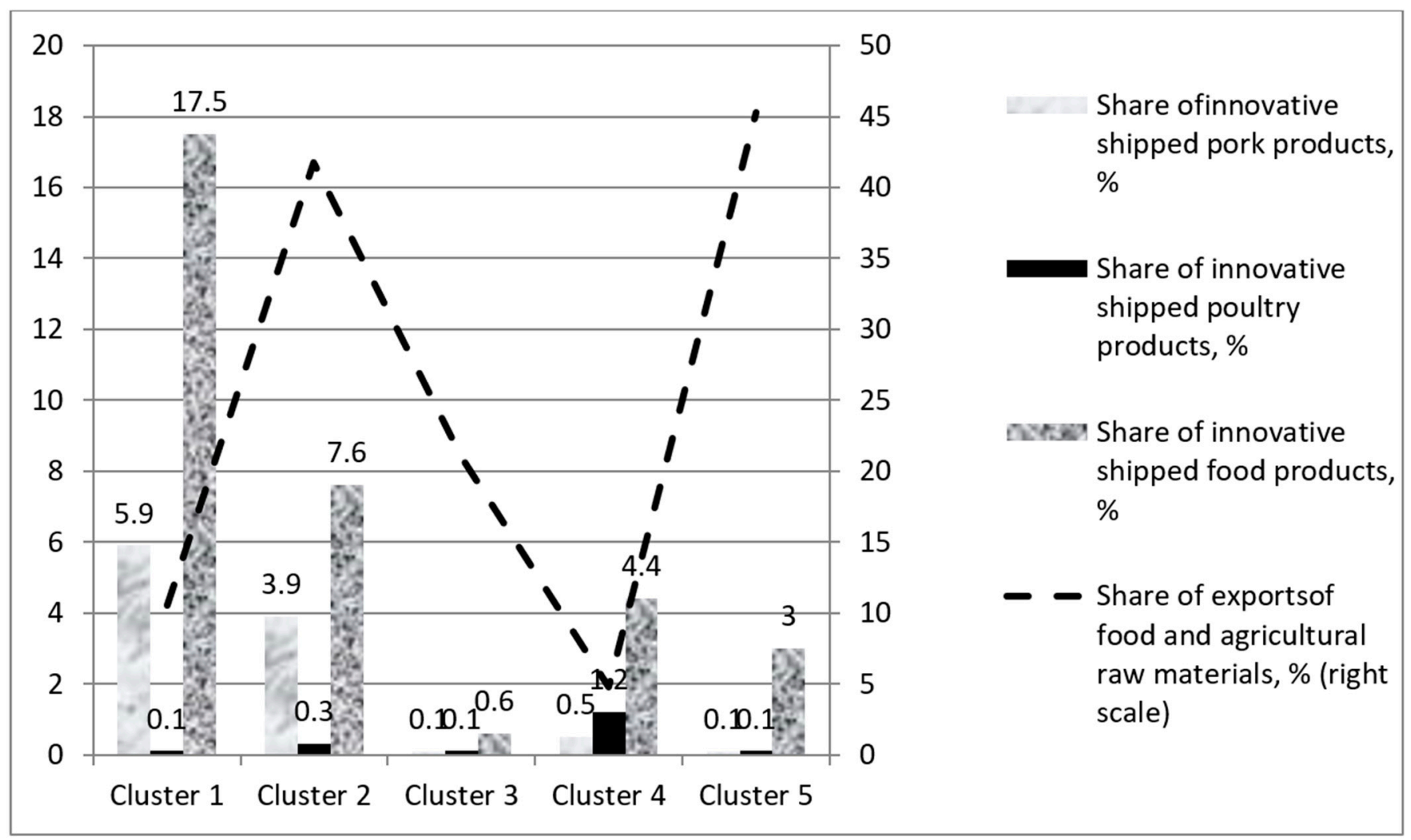

Figure 3. The relationship between food exports and innovative shipped goods across various activities.

The first cluster had the majority of innovative products shipped in pig farming and food products, although the share of food exports (10.5\%) was lower than in the second, third, and fifth clusters $(41.8 \%, 21.0 \%$, and $45.3 \%)$. The Belgorod region (the first cluster) is characterized by high investment attractiveness and innovative activity of agricultural organizations and food production, which characterizes the significant innovative potential of food and agricultural raw materials. In the second cluster, compared to the other three clusters, there were more innovative products shipped in pig farming $(3.9 \%)$ and food production $(7.6 \%)$, which also indicates the possibility of innovative exports. In the third cluster, there was almost no supply of innovative products in pig and poultry farming. Therefore, the possibilities for export of high-tech products are also limited, despite the significant share of exports of food and agricultural raw materials (21.0\%). In comparison with the third cluster, the innovation component of shipped goods in pig farming (1.2\%) and food production (4.4\%) was slightly higher in the fourth cluster, although the scale of food exports was small (4.8\%). The fifth cluster with export specialization in grain deserves special attention, and the share of innovative goods shipped in one of the cluster regions, Krasnodar territory, was 5.2\% (the highest level among the regions of all clusters). Therefore, in the fifth cluster, the grain export potential was the most significant.

\section{Discussion}

5.1. Discussion: Innovations and Investments for the Formation of an Export-Oriented Agricultural Economy

5.1.1. Author's Approach

Based on the results of the application of factor analysis, an underestimated role of indicators of investment in agriculture and the intensity and efficiency of agricultural production was established in comparison with the absolute gross indicators of production and export of agricultural products. In contrast to the numerous works of Russian scientists who have used the method of cluster analysis to study local problems of the 
development of the agro-industrial complex (investment potential, milk production and consumption, development of social infrastructure), the obtained author's results indicate a fundamentally new approach to identifying the relationships between investments in fixed assets in agriculture, gross production, and export of agricultural products on the basis of building a classification of Russian regions by factors that aggregate these features and characterize the production, investment, and export potential.

The paper substantiates the methodology for assessing the impact of investments in agriculture on the export potential of regional agrosystems using the cluster approach to assessing the functioning. On the basis of the analysis of innovative activity, an assessment of the innovative possibilities of exporting certain types of food of the selected cluster groups of regions was presented.

The novelty of the author's approach is also confirmed by the use of fundamentally new indicators of export and export by types of agricultural products in the regional context. Based on the results of the cluster analysis, recommendations were developed to increase the innovation and investment activity of agriculture in the regions in the context of the formation of an export-oriented economy, the need for the development of which is confirmed by the continuing trend in the majority of Russian regions of insufficient investment in the agro-industrial complex and the low efficiency of state investment support [52-54].

\subsubsection{State Support for Agriculture}

The downward trend in state participation in supporting agriculture is also observed in foreign countries. The regulation of state support for agriculture in most European countries is carried out on the basis of harmonization of national and supranational legislation within the framework of the Common Agricultural Policy.

The Europe 2020 strategy is the basis for developing national strategies for sustainable growth. The European Fund for Sustainable Development (EFSD) has operated since 2018 and is designed to financially support countries in need. At the same time, within the united Europe, difficulties have not been overcome in the development of country and pan-European indicators.

Private investors, on the other hand, have taken a more active position in the agri-food complex [55]. In Hungary and Poland, private investors are companies engaged in the production of agricultural raw materials, tractors, and combines [56,57].

\subsubsection{State Support for Exports and Investments}

The rating of the importance of measures of state support for export of products, compiled by Deloitte specialists in 2019 based on expert assessments of representatives of agribusiness companies, showed that $54 \%$ of respondents rated subsidies as the most important measure of state support. Meanwhile, $41 \%$ of representatives of small and medium-sized businesses and 14\% of large businesses rated the reduction of taxes and duties as the most important measure. The need to use such a measure as supporting the creation of market infrastructure was noted by $43 \%$ of respondents of large companies and $24 \%$ of small- and medium-sized businesses.

On the topic of researching the effectiveness of state support for investment activities in the agro-industrial complex, one can note a cycle of works by scientists from the NorthWest Research Institute of Economics and Organization of Agriculture.

\subsubsection{Innovations and Investments for the Formation of an Export-Oriented} Agricultural Economy

The cited sources indicate the intersectoral and interregional disproportions in attracting investment in the agro-industrial complex, and the greatest investment activity has been traced to the industrial branches of animal husbandry. Considering this form of state support for investment lending as subsidizing the interest rate, the authors noted its insufficient role in ensuring the continuity of the modernization process. 
Previous research has established that subsidizing the interest rate on investment loans to dairy farming organizations has an indirect effect on innovative development, and the interregional differentiation of subsidies to reimburse the costs of modernizing dairy farming facilities reflects "spot" bursts of modernization, especially in regions with a lower level of development.

The use of cluster analysis in the study of production, investment, and export potential made it possible to determine regional differences in the level of investment in agriculture, production volumes of main types of products, and food export. The factor analysis of the indicators presented in the model revealed three main components: First, the export of food and agricultural raw materials, determined by the production and export of grain; second, the efficiency of agricultural production, which depends on the production and export of meat and meat products; and third, the intensity of investment in agriculture and exports, with the capital intensity of agricultural products having a direct impact on the share of exports of food and agricultural raw materials.

A more detailed analysis of indicators by cluster groups reflects multidirectional trends in the formation of export and investment potential. The dominance of the first cluster (Belgorod region), in terms of agricultural production efficiency, is primarily explained by the region's livestock specialization and the possibilities for further expansion of innovative exports of livestock and poultry meat, although the capital intensity of agricultural products is lower than in the second, third, and fifth clusters.

In the second cluster, the share of exports of food and agricultural raw materials was quite high $(41.8 \%)$ compared to the fifth cluster (45.3\%). However, the regions of the second cluster are characterized by the diversification of exports. The Kaliningrad region and the Kamchatka territory specialize in the export of fish; the Tambov region specializes in the export of grain, vegetable oil, turkey meat; and the Leningrad region specializes in the export of fish, meat, and dairy products. The second cluster was characterized by the highest investment capacity of agriculture (RUB 143.1 per RUB 1000 of gross output) and high efficiency of agriculture (gross agricultural output per 1 ha of agricultural land is RUB 62,900). Possibilities for export growth are confirmed by the intensity of interregional supplies of grain and meat, with innovative exports mainly covering food products and pig breeding.

In the third and fourth-the most numerous clusters-there was a pronounced interregional differentiation of food exports and investments. For example, in the third cluster, the share of food exports in the Primorsky territory and the Amur region was high (44.3-45.6\%), while in the Yaroslavl and Vologda regions, it was practically absent $(0.4-0.5 \%)$, despite relatively high capital intensity of agricultural products. In general, both the third and fourth clusters are characterized by lower efficiency of agriculture. In the fourth cluster (with the exception of the Stavropol territory; the Chuvash Republic; the Volgograd, Novosibirsk, Kurgan, Saratov, and Omsk regions; and the Altai Territory), the share of food exports was less than average across Russia (5.9\%). The intensity of investments in the fourth cluster also lagged behind the indicators of other clusters, and a number of regions of the Volga Federal District should be noted as outsiders. Research has found that, in the third cluster, the possibilities for export supplies of high-tech goods are limited, despite a significant share of exports of food and agricultural raw materials $(21.0 \%)$. Compared to the third cluster, in the fourth cluster, the innovative component of shipped goods in pig breeding (1.2\%) and food production $(4.4 \%)$ was slightly higher, although the scale of food exports was small (4.8\%).

The fifth cluster, consisting of the Krasnodar Territory and the Rostov Region, was the leader in food exports (45.3\%), mainly due to grain. The cluster's production efficiency and investment intensity were average. However, the innovative potential of grain exports was the most significant.

The new export policy stimulates an increase in the production of products with high added value, which is most typical for processed products. According to the Ministry of Agriculture of Russia, in 2019, the number of investment projects for the creation of 
new enterprises in Russian regions reached 500. For all regions, production and export targets have been set taking into account the existing conditions for their growth. Therefore, for practically all clusters, it is necessary to provide conditions for attracting investment resources in the development of industries that carry out deep processing of raw materials. Updating the technological base of agricultural production as one of the priority areas of innovation and investment will be accompanied by the process of innovative structural transformation of the resource potential of agricultural production, which largely determines the possibilities of creating competitive science-intensive products [58].

The first cluster has achieved the highest efficiency of agricultural production, with a significant innovative export potential of animal husbandry. To expand the export potential, an innovation and investment strategy is needed which should be aimed at more implementation of investment projects related to the digital economy.

In the second cluster, state support should contribute to the in-depth innovative development of animal breeding. Therefore, investments should be directed to the production and processing of products with a high share of added value.

For the third and fourth clusters, investment mechanisms are needed that contribute to the formation of appropriate specialization, taking into account the interests of commodity producers and ensuring the sustainable development of regional agrosystems, including the creation of appropriate infrastructure facilities. An important condition for increasing the efficiency of the use of investment resources is the improvement of the guarantee and collateral systems. Some regions of Russia are quite successful in using such measures. For example, in the Novosibirsk region, which is the part of the fourth cluster, a special guarantee fund issues guarantees within $70 \%$ of a loan under loan agreements to consumer cooperatives, small- and medium-sized agricultural organizations, and peasant (farmer) enterprises [59].

Given the rather heterogeneous institutional structure of agricultural production in the third and fourth clusters, we believe that certain regions need measures to stimulate the employment of the rural population and to model effective integration ties with agricultural and processing organizations. The system for supporting the export activities of small- and medium-sized Russian enterprises has great advantages.

In the fifth cluster, investment should be aimed at creating an export-oriented infrastructure of the grain market using the mechanisms of concessional lending and compensation for part of the cost of transporting grain by road, rail, and water transport at the expense of the federal budget.

Thus, further stimulation of innovation and investment activity will help to increase the efficiency of agricultural production in order to create an export-oriented agricultural sector of the economy.

\subsection{Discussion: Open Innovation and the Formation of an Export-Oriented Agricultural Economy}

The most widespread concept of open innovation is the Chesbrough approach [60]. Chesbrough characterizes open innovation as multidirectional flows of knowledge (produced and consumed by the firm) aimed at fostering internal innovation and expanding the market for external application of innovative results. Strengthening cooperation in research and development and more active use of external resources play an important role in generating new ideas and in their rapid market promotion.

In modern conditions, many scientists associate the problem of open innovation with various aspects of economics, business, and management.

National innovation systems are models of innovation production at the macro level, among which the concept of a four-link spiral has emerged relatively recently.

The widespread concept of the four-link helix complements the triple helix paradigm by including the society - the end user of innovations - in the innovation process, which is designed to influence the creation of knowledge and technologies. In addition, the four-link "model is quite suitable for developing 'smart' strategies specialization" as an element of a locally oriented innovation policy. The implementation of this innovation policy will 
require the use of fundamentally new tools. In addition, it is quite problematic to quantify the effect of "smart specialization" [61].

The study of the micro- and macro-dynamics of open innovations as a further development of the four-link spiral concept is of great interest. The research model of foreign scientists is based on the concept of social, environmental, economic, cultural, political, and information sustainability, and the role of participants in the innovation process has gradually transformed. The state has lost a number of regulatory functions, higher education institutions are actively involved in technology transfer and joint knowledge creation, and societies and consumers are involved in the processes and commercialization of knowledge [62].

A new stage of development of the countries of the world (Globalization 2) is associated with a new concept of the world order and strengthening international cooperation in innovation at the regional and bioregional innovation systems [63].

The strengthening of regionalization processes is accompanied by increased competition between business organizations and the emergence of new educational competencies which enable users to use new knowledge and work on new technologies. Accordingly, for the development of business strategies, the system of intellectual knowledge, formed through research, development, and innovation, is becoming increasingly important.

Modeling a modern economy can be represented by business cyclical dynamics of open innovation with three sub-economies (market open innovation including Startups, closed, open innovation, big business, and social).

The level of balance between sub-economies determines the country's economic growth rate. For example, in the case of strong differentiation in the scale of activity of sub-economies, economic growth slows down. The presence of an average balance between the three sub-economies means a fairly significant scale, which leads to the achievement of high rates of economic growth [64].

A rather complex solution is associated with the problem of organizing a "culture for the dynamics of open innovation," the purpose of which, according to some authors, is to motivate the dynamics of open innovation and control the complexity of open innovation. A great practical value, in our opinion, lies in the developed conceptual model of culture in entrepreneurship. Researchers have confirmed this model with the help of an indirect social experiment. The conceptual model of the culture of open innovation dynamics is based on the interaction of three dimensions: The entrepreneurship of beginning entrepreneurs, intra-entrepreneurship of employees of an existing company, and organizational entrepreneurship of the company itself. Depending on the balance of the three types of sub-entrepreneurship, the culture of open innovation dynamics can have different priorities, with the entrepreneurial prioritizing a culture of open innovation dynamics, the intra-entrepreneurial prioritizing a culture of open innovation dynamics, and the organizational entrepreneurial prioritizing a culture of open innovation dynamics [65].

Foreign experience in the organization of entrepreneurship shows the possibilities of using open innovations in the restaurant business. It should be noted the undoubted value of the research model of the open innovation ecosystem of restaurants with open innovation ingredients, open innovation recipes, and open innovation services intended for the analysis of open innovations in small restaurants. The results of the research carried out using sociological methods confirm the need for open innovations for a successful business. An open innovation strategy allows business owners to maintain a competitive advantage, and the use of an open innovation platform for food ingredients, recipes, or services brings additional income [66].

The effectiveness of the open innovation model is also confirmed by the example of the regional innovation system [67]. Considering the process of developing innovative strategies of firms in the natural sciences industry as described by Emilia-Romagna, the authors compared the closed innovation model of internal R\&D with the model of open innovation. The second model reflects the interactive combinatorial process of internal and external sources of knowledge and learning information, which is more preferable. 
We share the views of the above authors and attempt to adapt the possibility of applying the concept of open innovation to the formation of an export-oriented agricultural economy together with the theory of national innovation systems, the theory of international trade, the theory of spatial development, and the theory of three-phase economic development.

We believe that improving the efficiency of agricultural production will increase the export potential and sustainability of the agrarian economy based on the adaptation of the concept of open innovation and the synthesis of theories of innovation-investment development and export in the transition to Industry 4.0. In this paper, we attempted to study the micro-and macro-dynamics of open agricultural innovations in improving the efficiency of agricultural production and increasing export potential in regions and sectors with the input of investment resources. On the basis of open databases and catalogues of scientific and technical products of the leading agricultural universities of Russia which provide the generation and flow of knowledge, the role of open agricultural innovations for the successful conduct of agribusiness is scientifically substantiated. The formation of innovative and investment agricultural systems based on the synergy of interaction between the state, business, science, society, and information support will increase the stability of the agricultural economy and ensure an increase in its growth rates.

Russia has a huge territory, and the formation of a sustainable agricultural economy is influenced by numerous factors: Natural and climatic, geographical, environmental, economic, technological, and social. The pronounced spatial asymmetry in the conduct of agricultural production does not allow industries to achieve uniform sustainable growth rates. In this article, it is proposed to consider the possibilities of improving the state policy, taking into account the level of innovation and investment development of the selected clusters.

The implementation of a breakthrough scenario of an export-oriented agricultural economy involves the use of new measures of state support that contribute to the transition to an open innovation model in the agricultural sector.

The first direction covers measures to create products with high added value based on the technological re-equipment of the industry, which predetermines the need to assess the scientific and intellectual potential of agriculture and the agro-food complex.

The second direction involves the creation of an export-oriented infrastructure of food markets using new mechanisms to stimulate technology transfer.

For a radical change in the structure of food exports, preference for state support will be given to large and largest investment projects for deep processing of agricultural products for which the use of open innovations will increase the efficiency of production and investment.

\section{Conclusions}

6.1. The Value of This Research

6.1.1. Results of the study

In the context of the innovative transformation of the economy, the role of state policy in monitoring and searching for tools to improve the efficiency of the functioning of agricultural systems at all levels of management increases.

The study presents the possibilities of modeling the impact of innovation and investment development on the formation of an export-oriented agricultural sector of the economy using the developed tools for diagnosing the state and functioning of regional and sectoral agricultural systems. The results can be successfully used to predict development scenarios and substantiate management decisions by regional experts.

In the work, the systematization of factors of production, investment, and export potential of the agro-industrial complex of Russia was carried out by conducting a hierarchical regional classification. According to the results of the simulation, the relationships between investments in fixed assets of agriculture, gross output of the industry, and export of agricultural products were revealed based on the construction of a classification 
of Russian regions by factors that aggregate these features and characterize production, investment, and export potential. The study provides an assessment of the innovative profile of investment activity in the regions of cluster groups and determines its impact on the formation of export potential.

\subsubsection{Practical Significance}

The problems of strategic management and support for making managerial decisions in the field of innovative development of regional agrosystems, for which traditional research methods are ineffective, can be solved using the proposed tools of the diagnostics and monitoring of the state of regional innovative agricultural systems.

The use of the suggested model will improve the reliability and quality of analysis and modeling of problems in regional agricultural systems with a high level of differentiation. Based on the results of the cluster analysis, recommendations were developed to increase the innovation and investment activity of agriculture in the regions in the context of the formation of an export-oriented economy, the need for the development of which is confirmed by the continuing tendency of insufficient investment in the agro-industrial complex in most Russian regions and the low efficiency of state investment support.

\subsubsection{Research Limitations}

The limitations of the study can be associated with both the primary statistical data for calculating indicators and constructing econometric models and the chosen research methodology.

Within the framework of improving the system of statistical indicators of the innovative activity of economic entities, one can rely on the achievements of foreign science. The problem of measuring innovative activity has been raised in the works of many authors. In our opinion, it is necessary to develop and put into practice more detailed forms of statistical reporting and on an ongoing basis to publish detailed data in a regional context on the volume of goods, works, and services produced using marketing innovations. Marketing innovations include high-tech products and costs of marketing innovations, including types of innovations and types of products and services provided. It is also important to consider selective data on the assessment by leaders of organizations implementing innovations in order to ensure readiness to implement marketing innovations and their effectiveness.

\subsection{Implication}

\subsubsection{Recommendations}

One of the conditions for diversifying food exports is to stimulate the production of innovative goods with high added value, which is relevant for the overwhelming majority of regions of Russia.

Based on the results of the research, for the regions of all cluster groups, we recommend providing conditions for increasing the innovative activity of agricultural organizations by more actively attracting investment resources in the development of industries that carry out the deep processing of raw materials.

In order to achieve the targeting of government support measures, it is advisable to use such instruments as subsidizing investment lending, stimulating the purchase by agricultural producers of machinery and equipment with a high innovative component, and reimbursing of part of the direct costs of the creation and modernization of facilities.

Further recommendations were formulated, taking into account the achieved level of agricultural production efficiency and the diffusion of innovations.

The first cluster, represented by the Belgorod region, was distinguished by the highest efficiency of agricultural production and had a significant innovative export potential of animal husbandry.

To expand the export potential, an innovation and investment strategy is needed, which should be aimed at introducing investment projects related to the digital economy. 
The regions of the second cluster had a high level of investment, but in terms of the scale of production and implementation of innovative products, they were still inferior to the first cluster. This fact prevents the implementation of innovative structural transformations. Taking into account the specifics of regional specialization, it is recommended to strengthen the targeting of measures of state support for transfer and technology transfer for the in-depth innovative development of animal husbandry.

The third and fourth clusters were characterized by a weak innovation potential for the production of grain and livestock products. For the regions of these clusters, the creation of infrastructure facilities and an increase in the cost of technological innovation are recommended. In some regions, the share of households in the production of agricultural products was high. In relation to these regions, it is recommended to use measures to stimulate employment of the rural population and to model effective integration ties with agricultural and processing organizations. A special role is played by the support system for export activities (including innovative ones) of small- and medium-sized Russian enterprises.

The fifth cluster was represented by the largest grain exporting regions. To increase innovation and investment activity, the investment strategy should be aimed at creating an export-oriented infrastructure of the grain market. More active use of the mechanisms of concessional lending and compensation of part of the cost of transporting grain by road, rail, and water transport at the expense of the federal budget is recommended.

The implementation of the formulated conclusions, concepts, developed approaches, and methods will provide an integrated approach to the analysis and assessment of the effectiveness of regional agricultural systems, which consists in the possibility of using state innovation policy in the agricultural sector of the economy in accordance with the needs of specific regions in order to increase its export potential.

\subsubsection{Prospects for Further Research}

In further research, we plan to develop methodological approaches to assessing and forecasting the optimal level of investment in the agro-industrial complex of Russian regions in order to increase export potential. Within the framework of the theory of structural transformations of an underdeveloped economy, described by Chenery $\mathrm{H}$. and Straut A. (the theory of "three-phase development"), a fundamentally new solution will be to substantiate theoretical and methodological provisions for the development of key strategies for managing the investment potential of the region. This new solution will be formed as a result of adjusting the methodological approaches to the distribution of budgetary funds for development agro-industrial complex and by taking into account the priorities for the development of export potential.

The new solution is expected to develop predictive models to determine the optimal level of investment in agricultural science in order to ensure sustainable development of regional agrosystems. This topic is of interest to foreign researchers [68]. The substantiation of key strategies for managing the investment potential of the region and the development of predictive scenarios for the investment development of the regions are aimed at increasing the export potential. A system of selection of promising investment projects in the agro-industrial complex will be substantiated in order to harmonize federal and regional investment policies.

Author Contributions: Conceptualization, M.Y.V. and E.A.D.; Data curation, A.P.P.; Formal analysis, V.L.S. and M.Y.V.; Funding acquisition, M.Y.V.; Investigation, M.Y.V.; Methodology, V.L.S. and E.A.D.; Project administration, M.Y.V. and E.A.D.; Resources, V.L.S. and A.P.P.; Software, V.L.S.; Supervision, M.Y.V.; Validation, M.Y.V.; Visualization, M.Y.V., E.A.D. and A.P.P.; Writing—original draft, V.L.S., M.Y.V. and E.A.D.; Writing-review \& editing, E.A.D. All authors have read and agreed to the published version of the manuscript.

Funding: The reported study was funded by the Russian Foundation for Basic Research according to the research project $\mathrm{N}^{\circ} 20-010-00979 \mathrm{~A}$ «Influence of investment resources of regional agricultural systems on increasing export potential in the conditions of innovative structural transformation». 
Institutional Review Board Statement: Not applicable.

Informed Consent Statement: Not applicable.

Data Availability Statement: Data sharing is not applicable to this article.

Conflicts of Interest: The authors declare no conflict of interest.

\section{References}

1. Patuk, I.; Hasegawa, H.; Borodin, I.; Whitaker, A.C.; Borowski, P.F. Simulation for Design and Material Selection of a Deep Placement Fertilizer Applicator for Soybean Cultivation. Open Eng. 2020, 1, 733-743. [CrossRef]

2. Patuk, I.; Borowski, P.F. Computer aided engineering design in the development of agricultural implements: A case study for a DPFA. J. Phys. Conf. Ser. 2020, 1679, 052005. [CrossRef]

3. Menshikov, S.M.; Klimenko, L.A.; Freeman, C. Long Waves in the Economy: When Society Changes Its Skin; Lenand: Moscow, Russia, 2014; pp. 208-214.

4. Lundvall, B.A. National Systems of Innovation: Towards a Theory of Innovation and Interactive Learning; Pinter Publishers: London, UK, 1992.

5. Yun, J.J.; Won, D.; Park, K. Dynamics from open innovation to evolutionary change. J. Open Innov. Technol. Mark. Complex. 2016, 2, 7. [CrossRef]

6. Aker, J. Dial «A» for Agriculture: Using ICTs for Agricultural Ex-tension in Developing Countries. Agric. Econ. 2011, 42, 31-47. [CrossRef]

7. Krugman, P.R. Increasing Returns, Monopolistic Competition and International Trade. J. Int. Econ. 1979, 9, 469-479. [CrossRef]

8. Chenery, H.B. The structuralist approach to development policy. Am. Assoc. Pap. Proc. 1975, 65, 310-316.

9. Al-Hassan, R.; Egyir, I.; Abakah, J. Farm household level impacts of information communication technology (ICT)-based agricultural market information in Ghana. J. Dev. Agric. Econ. 2013, 5, 161-167. [CrossRef]

10. Borowski, P.F. Nexus between water, energy, food and climate change as challenges facing the modern global, European and Polish economy. AIMS Geosci. 2020, 6, 397-421. [CrossRef]

11. Barrett, C.; Barbier, E.; Reardon, T. Agro-Industrialization, Globalization and International Development: Environmental implications are devoted to the study of trends in the global economy and their impact on improving the efficiency of innovation. Environ. Dev. Econ. 2001, 6, 419-433. [CrossRef]

12. Busch, L.; Bain, C. New! Improved? Transformation of the global agri-food system. Rural Sociol. 2004, 3, 321-346. [CrossRef]

13. Autor, D.H. Why are there still so many jobs? The history and future of workplace automation. J. Econ. Perspect. 2015, 29, 3-30. [CrossRef]

14. Gandhi, R.; Veeraraghavan, R.; Toyama, K.; Ramprasad, V. Digital Green: Participatory Video and Mediated Instruction for Agricultural Extension. Inf. Technol. Int. Dev. 2009, 5, 1-15.

15. Dasgupta, S.; Mamingi, N.; Meisner, C. Pesticide Use in Brazil in the Era of Agro-industrialization and Globalization. Environ. Dev. Econ. 2001, 4, 459-482. [CrossRef]

16. Oliver, Y.; Robertson, M.; Wong, M. Integrating farmer knowledge, precision agriculture tools, and crop simulation modeling to evaluate management options for the poor-performing patches in cropping fields. Eur. J. Agron. 2010, 32, 40-50. [CrossRef]

17. Henson, S.J.; Reardon, T. Private Agrifood Standards: Implications for Food Policy and the Agrifood System. Food Policy 2005, 3 , 241-253. [CrossRef]

18. Humphrey, J.; Schmitz, H. Governance in Global Value Chains. IDS Bull. 2001, 3, 19-29. [CrossRef]

19. Paptsov, A.G.; Nechaev, V.I.; Mikhailushkin, P.V. Towards to a single innovation space on the agrarian sector of the member states of the Eurasian economic union: A case study. Entrep. Sustain. Issues 2019, 7, 637-648. [CrossRef]

20. Sandu, I.S.; Veselovsky, M.Y.; Semyonova, E.I.; Fedotov, A.V.; Doshchanova, A.I. Methodological aspects of social and economic efficiency of the regional activities. J. Adv. Res. Law Econ. 2015, 6, 650-659.

21. United Nations. The Transformation of Our World: An Agenda for Sustainable Development for the Period up to 2030; United Nations: Rome, Italy, 2015.

22. Vasilchenko, M.Ya.; Derunova, E. Factors of investment attractiveness of Russian agriculture in the context of innovative structural adjustment. Sci. Pap. Ser. Manag. Econ. Eng. Agric. Rural Dev. 2020, 2, 511-522.

23. Derunova, E.A.; Ustinova, N.V.; Derunov, V.A.; Semenov, A.S. Modeling of diversification of market as a basis for sustainable economic growth. Econ. Soc. Chang. Facts Trends Forecast 2016, 6, 91-109. [CrossRef]

24. Sandu, I.S.; Glagolev, S.N.; Doshanova, A.I.; Troshin, A.S.; Lomachenko, S.N. Formation features of higher school innovation model in modern conditions. Int. Bus. Manag. 2015, 9, 1102-1107.

25. Coelli, T.; Rao, D.S.P.; Battese, G.E. An Introduction to Efficiency and Productivity Analysis, 2nd ed.; Springer: New York, NY, USA, 2005.

26. Malmquist, S. Index numbers and indifference surfaces. Trab. Estat. 1953, 4, 209-242. [CrossRef]

27. Caves, D.W.; Christensen, L.R.; Diewert, W.E. The Economic Theory of Index Numbers and the Measurement of Input, Output, and Productivity. Econometrica 1982, 50, 1393-1414. [CrossRef]

28. Cooper, W.; Seiford, L.; Zhu, J. Data Envelopment Analysis: History, Models, and Interpretations. In Handbook on Data Envelopment Analysis; International Series in Operations Research \& Management Science; Springer: Boston, MA, USA, $2011 ;$ pp. 1-39. 
29. Thanassoulis, E. Introduction to the Theory and Application of Data Envelopment Analysis: A Foundation Text with Integrated Software; Kluwer Academic Publishers: Boston, MA, USA, 2001.

30. Tone, K. Advances in DEA Theory and Applications: With Extensions to Forecasting Models; John Wiley \& Sons: New York, NY, USA, 2017.

31. Aggarwal, C.C. Data Clustering; Chapman and Hall/CRC: Boca Raton, FL, USA, 2013.

32. Wierzchoń, S.T.; Kłopotek, M.A. Modern Algorithms of Cluster Analysis; Studies in Big Data; Springer: New York, NY, USA, 2017; pp. 9-66.

33. Kaufman, L.; Rousseeuw, P.J. Clustering by means of medoids. In Statistical Data Analysis Based on the L1-Norm and Related Methods; Dodge, Y., Ed.; Elsevier: Amsterdam, The Netherlands, 1987; pp. 405-416.

34. Rokach, L.; Maimon, O. (Eds.) Clustering Methods. In Data Mining and Knowledge Discovery Handbook; Springer: Boston, MA, USA, 2005.

35. Davies, D.L.; Bouldin, D.W. A Cluster Separation Measure. IEEE Trans. Pattern Anal. Mach. Intell. 1979, PAMI-1, $224-227$. [CrossRef]

36. Dubrov, A.M.; Mkhitaryan, V.S.; Troshin, L.I. Multidimensional Statistical Methods: Textbook; Finance and Statistics: Moscow, Russia, $2003 ;$ p. 352.

37. Shubat, O.M.; Shmarova, I.V. Cluster analysis as an analytical tool for population policy. Econ. Reg. 2017, 13, 1175-1183. [CrossRef]

38. Larina, T.N. Multidimensional statistical analysis of the development of social infrastructure in rural areas of the Orenburg region. Reg. Econ. Theory Pract. 2009, 20, 49-53.

39. Guzairov, M.B.; Degtyareva, I.V.; Makarova, E.A. Expenditures of the population of the regions of the Russian Federation on food purchase: Component and cluster analysis. Econ. Reg. 2015, 4, 145-157.

40. Raiskaya, N.N.; Sergienko Ya, V.; Frenkel, A.A. Cluster analysis of Russian regions by the level of investment potential. Issues Stat. 2007, 5, 3-9.

41. Nechayev, V.; Artemova, E.; Bursa, I. The application of cluster analysis in the study of the efficiency of milk production in Krasnodar region. Agro-Ind. Complex Econ. Manag. 2011, 7, 24-29.

42. Ruchinskaya, L.V. Statistical analysis and forecasting of the market of milk and dairy products. Issues Stat. 2011, 11, 78-82.

43. Andryushchenko, S.A.; Vasilchenko, M.Ya. Regional conditions and opportunities for the development of dairy and meat cattle breeding in Russia. Agrar. Sci. J. 2016, 6, 73-81.

44. Färe, R.; Grosskopf, S.; Primont, D. Aggregation, Efficiency, and Measurement; Springer: New York, NY, USA, 2007.

45. Farrell, M.J. The Measurement of Productive Efficiency. J. R. Stat. Soc. Ser. A (Gen.) 1957, 120, 253-290. [CrossRef]

46. Derunova, E.; Kireeva, N.; Pruschak, O. Typology of regions according to the level of food security: Methodological approaches and solutions. Sci. Pap. Ser. Manag. Econ. Eng. Agric. Rural Dev. 2019, 19, 135-146.

47. Firsova, A.A.; Makarova, E.L.; Tugusheva, R.R. Institutional Management Elaboration through Cognitive Modeling of the Balanced Sustainable Development of Regional Innovation Systems. J. Open Innov. Technol. Mark. Complex. 2020, 6, 32. [CrossRef]

48. Mortensen, I.; Stendahl, P.; Walter, C. Oslo Manual—Guidelines for Collectingand Interpreting Innovation Data, 3rd ed.; Organisation for Economic Cooporation and Development: Paris, France, 2005; p. 192. [CrossRef]

49. Labianca, M.; de Rubertis, S.; Belliggiano, A.; Salento, A. Innovation in rural development in Puglia, Italy: Critical issues and potentialities starting from empirical evidence. Stud. Agric. Econ. 2016, 118, 38-46. [CrossRef]

50. Cheshire, P.C.; Malecki, E.J. Growth, Development, and Innovation: A Look Back and Forward. Pap. Reg. Sci. 2004, 83, 249-267. [CrossRef]

51. Crescenzi, R.; Rodriguez-Pose, A.; Storper, M. The Territorial Dynamics of Innovation: A Europe-United States Comparative Analysis. J. Econ. Geogr. 2007, 7, 673-709. [CrossRef]

52. Vasilchenko, M.Ya. The innovation process development in dairy cattle breeding in Russia. Rev. Espac. $2018,39,30$.

53. Vasilchenko, M.Ya. Mechanisms for implementing strategic priorities for the development of the production potential of dairy cattle breeding. Econ. Sci. 2019, 5, 46-50.

54. Derunova, E.; Kireeva, N.; Pruschak, O. The role of state support in ensuring the inclusive development of the agri-food system. Sci. Pap. Ser. Manag. Econ. Eng. Agric. Rural Dev. 2020, 20, 161-172.

55. Martin, S.J.; Clapp, J. Finance for agriculture or agriculture for finance? J. Agrar. Chang. 2015, 15, 549-559. [CrossRef]

56. Wigier, M.; Wieliczko, B.; Fogarasi, J. Impact of Investment Support on Hungarian and Polish Agriculture; Paper Prepared for Presentation for the 142nd EAAE Seminar Growing Success; Agriculture and Rural Development in an Enlarged EU; Corvinus University of Budapest: Budapest, Hungary, 2014.

57. Toumashev, A.R.; Toumasheva, M.V.; Valeev, E.R.; Miasnikov, D.A. Structural Changes in Russian Economy and Objectives of Investment Policy. Asian Soc. Sci. 2015, 11, 193-197. [CrossRef]

58. Vasilchenko, M.Ya.; Sandu, I. Innovative-investment development of agriculture in the conditions of formation of the exportoriented economic sector: System approach. Sci. Pap. Ser. Manag. Econ. Eng. Agric. Rural Dev. 2020, 20, 599-612.

59. Tyu, L.; Chirkova, I. Improving investment policy in agriculture in Siberia in modern conditions. Agro-Ind. Complex: Econ. Manag. 2017, 11, 62-71.

60. Chesbrough, H. Open Innovation: Where We've Been and Where We're Going. Res. Technol. Manag. 2012, 55, 20-27. [CrossRef] 
61. Carayannis, E.G.; Grigoroudis, E.; Campbell, D.F.; Meissner, D.; Stamati, D. The ecosystem as helix: An exploratory theorybuilding study of regional co-opetitive entrepreneurial ecosystems as Quadruple/Quintuple Helix Innovation Models. RED Manag. 2018, 48, 148-162.

62. Yun, J.J.; Zheng, L. Micro- and Macro-Dynamics of Open Innovation with a Quadruple-Helix Model. Sustainability 2019, $11,3301$. [CrossRef]

63. Cooke, P. Regionally Asymmetric Knowledge Capabilities and Open Innovation Exploring 'Globalisation 2' —A New Model of Industry Organization. Res. Policy 2005, 34, 1128-1149. [CrossRef]

64. Yun, J.J.; Won, D.; Park, K. Entrepreneurial Cyclical Dynamics of Open Innovation. J. Evol. Econ. 2018, 28, 1151-1174. [CrossRef]

65. Yun, J.J.; Zhao, X.; Jung, K.; Yigitcanlar, T. The Culture for Open Innovation Dynamics. Sustainability 2020, 12, 5076. [CrossRef]

66. Yun, J.J.; Park, K.; Gaudio, G.; Corte, V. Open innovation ecosystems of restaurants: Geographical economics of successful restaurants from three cities. Eur. Plan. Stud. 2020, 28, 2348-2367. [CrossRef]

67. Belussi, F.; Sammarra, A.; Sedita, S. Learning at the boundaries in an open regional innovation system: A focus on firms innovation strategies in the Emilia Romagna life science industry. In Proceedings of the DRUID Summer Conference 2007 on Appropriability, Proximity, Routines And Innovation, Copenhagen, Denmark, 18-20 June 2007.

68. Pray, C.E.; Fuglie, K.O. Private Investment in Agricultural Research and International Technology Transfer in Asia. Available online: http:/ /ageconsearch.umn.edu/record/33927/files/ae010805.pdf (accessed on 12 January 2021). 